\section{The Founding of Arsi University}

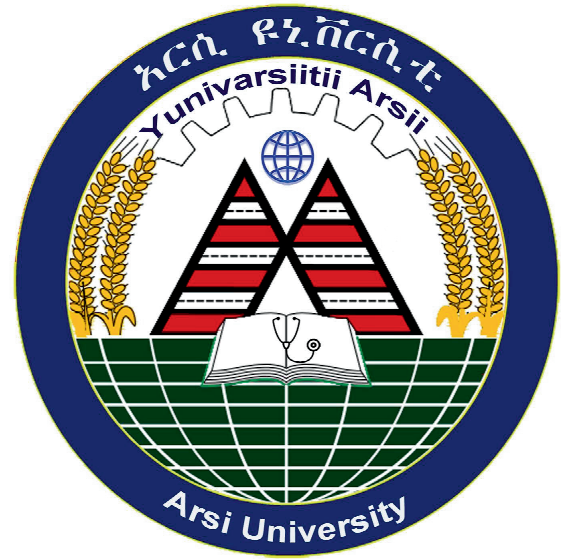

The logo of Arsi University

At the end of 2014, within the framework of a program for the establishment of new institutions of higher education all over the country, the Ethiopian government instigated the formation of the newly-founded Arsi University

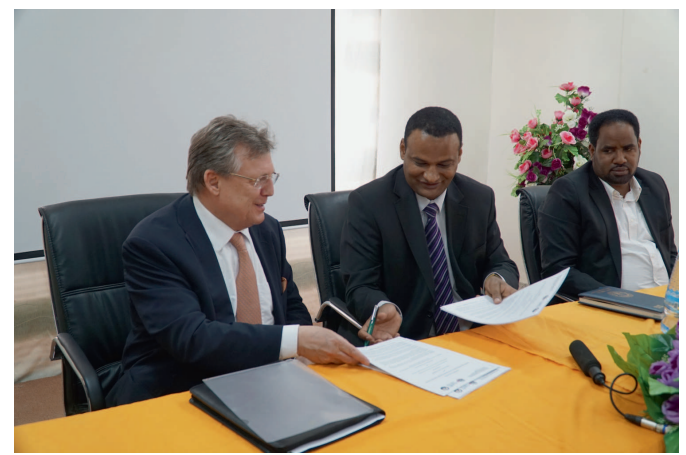

Signing the agreement in April 2015, I.t.r.: Professor Dr. Dieter Häussinger (Director of the HITM), Dr. Tolla Beriso (former President of Arsi University), Dr. Hirpho Teno (former Vice President of Arsi University)

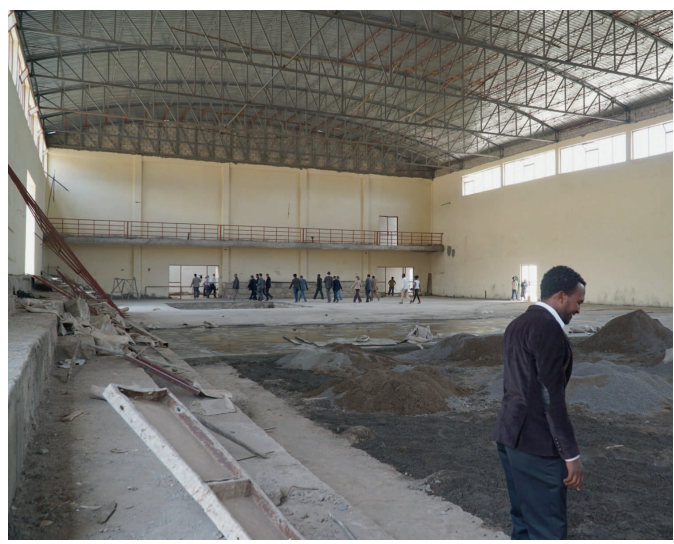

The gymnasium of Arsi University under construction

in Asella out of the faculties of the University of Adama (medicine, law, agricultural science, humanities, economics, and the physical education college).

As the new university of the Arsi zone based in Asella it took over the governance of the medical faculty and thus the local responsibility for the partnership with Heinrich Heine University. The former president of the newlyfounded Arsi University, Dr. Tolla Beriso, confirmed from the beginning his interest in continuing and extending the partnership. This was laid down in a cooperation agreement signed during a visit of Professor Dr. Häussinger and a German delegation in Asella in April 2015. In Arsi University Heinrich Heine University has gained an Ethiopian partner who is interested in furthering international education and academic training. The construction of much-needed new buildings at the hospital in Asella is also planned for the near future. After some years, Dr. Tolla Beriso was promoted to the Oromia state educational administration and Dr. Duguma took over as 


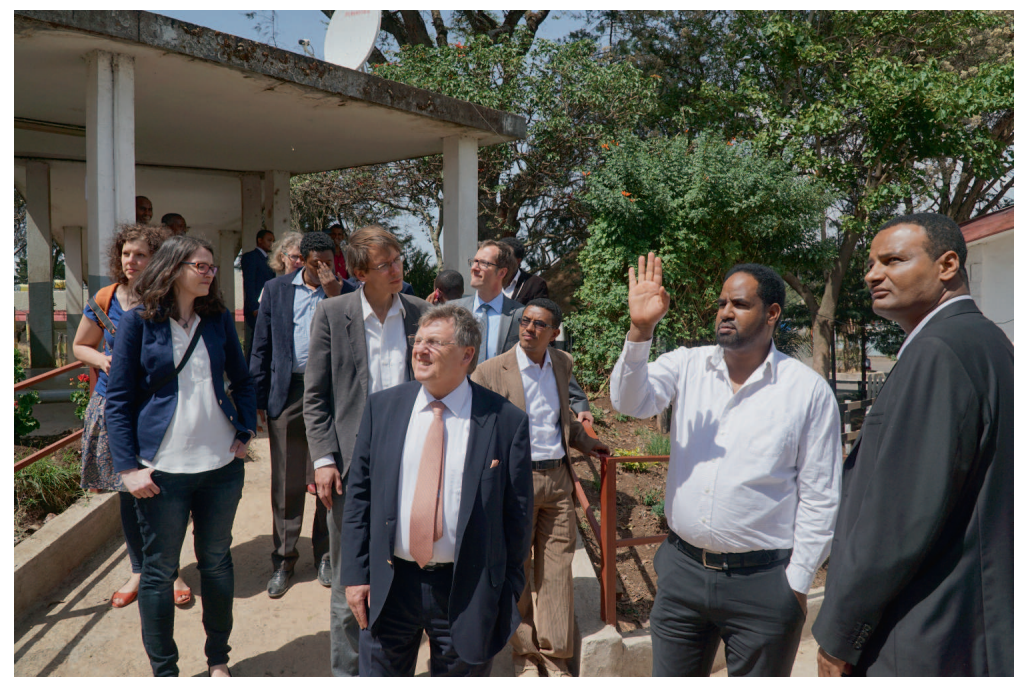

Tour of the hospital grounds during the meeting of the German and Ethiopian delegations (April 2015)

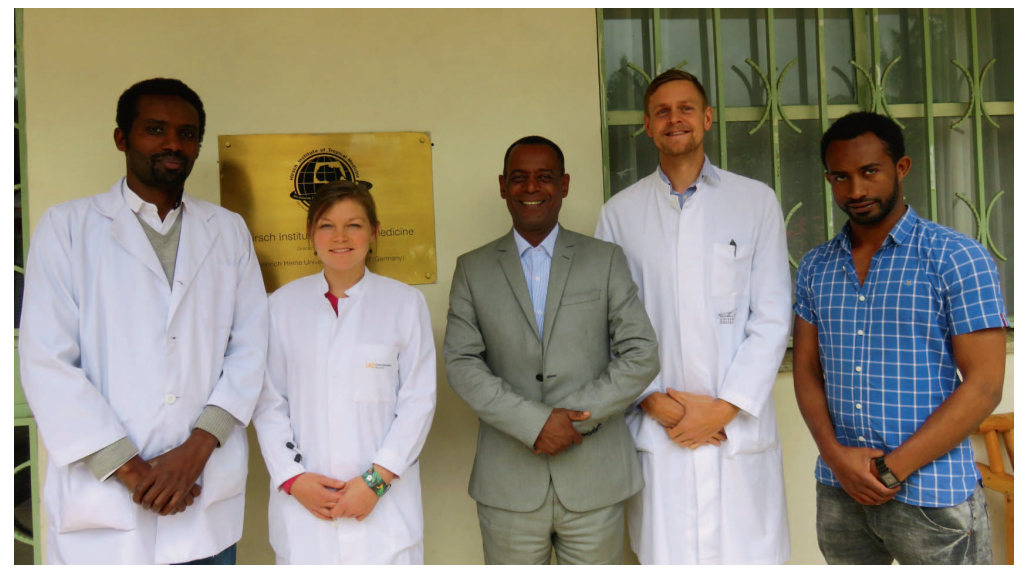

Meeting with Dr. Duguma, the new president of Arsi University

president of Arsi University. With him as president, the Ethiopian partner's interest in international cooperation, e.g. with the Hirsch Institute, has been intensified and the partnership is being continued with great motivation. 


\section{Arsi, a Land of Athletes}

The list of Olympic medalists from Ethiopia is impressive. The Ethiopian athletes have so far won 53 medals, all at the Summer Olympics. Especially the internationally famous marathon runners are remarkable, e.g. Haile Gebrselassie, who was born in Asella in 1973. All in all, he set 26 world records and he was Olympic champion twice (1996 in Atlanta and 2000 in Sydney, gold medal, 10,000 meters). He won the Berlin Marathon four times and the Dubai Marathon, one of the world's richest road races, three times. In April 2016, the Tirunesh Dibaba Athletics Training Center, which was named after a top Ethiopian athlete, was ceremoniously opened in Asella. On 45 hectares, the training center boasts not only a 400-m cinder track, but also a football field, tennis courts, common rooms for athletes and trainers, a library, a health clinic, and an administration building.

Kenenisa Bekele is one of the world's greatest long-distance runners. He also hails from the land of the Oromia. He is not only a three-time Olympic champion, but holds the world records in the 5,000 meters and 10,000 meters (in September 2016). The region has also produced top female athletes: Derartu Tulu won an Olympic gold medal in the women's 10,000 meters race twice, in Barcelona in 1992 and in Sydney in 2000. Ms. Tulu owns and manages the first-class Deratu Tulu Hotel in Asella, which was named after her and has been praised and recommended in various internet portals. The staff of the institute have very often enjoyed dining at the splendid hotel restaurant.

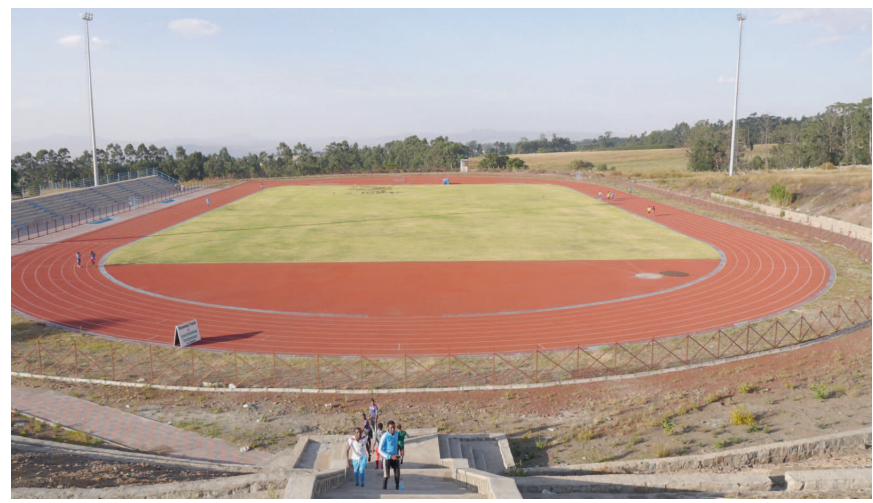

The cinder track of the Tirunesh Dibaba Athletics Training Center, which belongs to the Physical Education College of Arsi University in Asella 


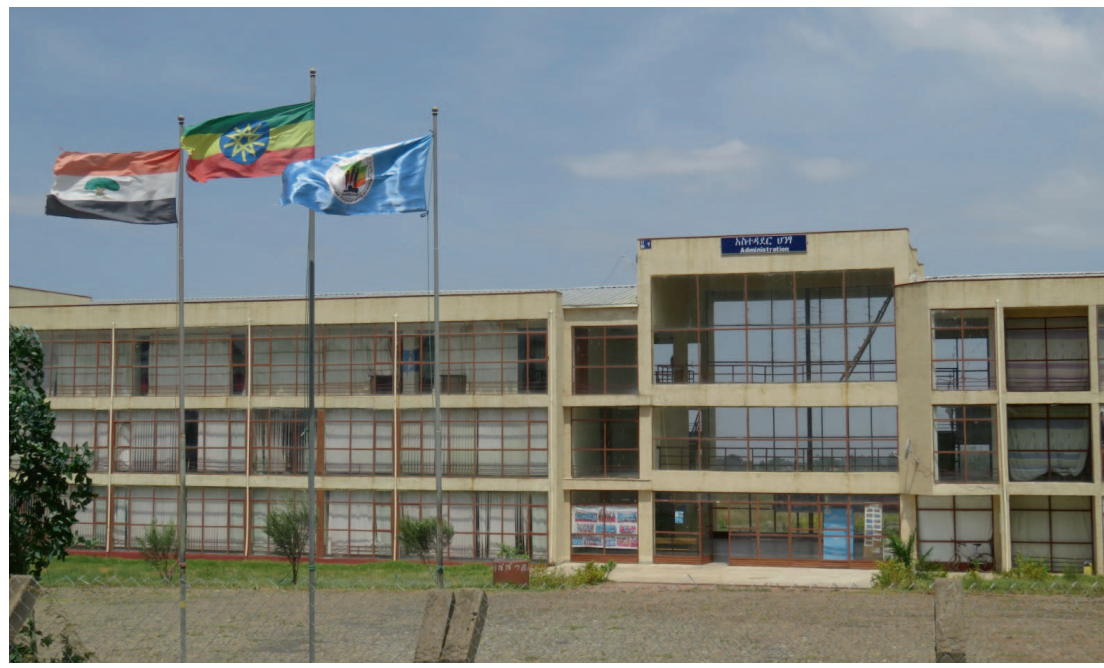

The main campus of the Tirunesh Dibaba Training Center

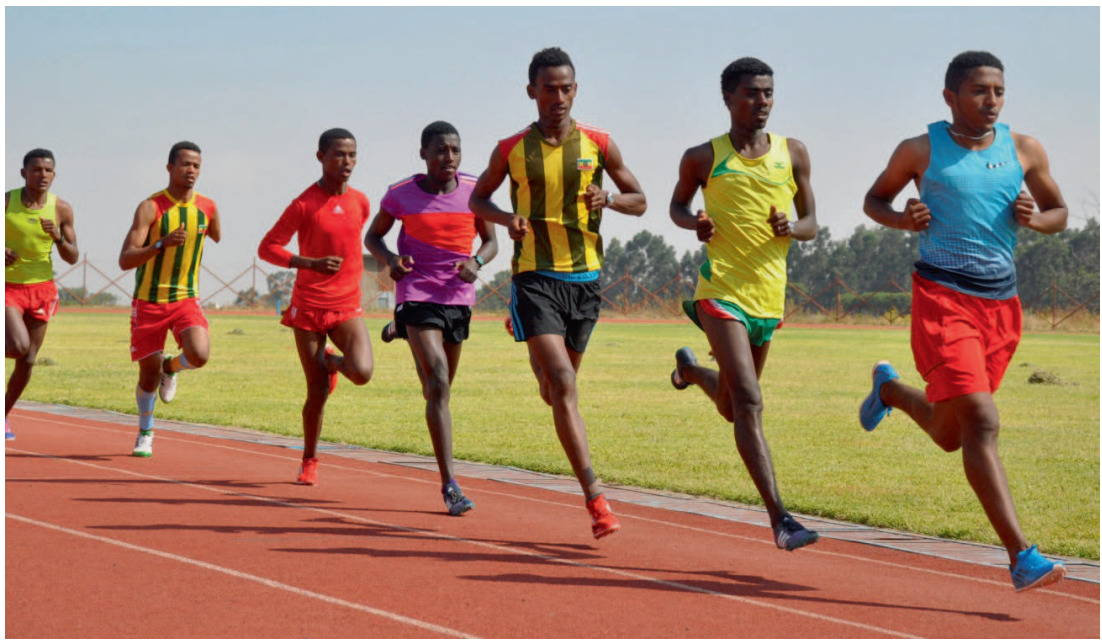

November 2016: young athletes training 
These Ethiopian runners train in simple conditions in the surroundings of the Physical Education College and thus in close proximity to our houses. Hence, the coordinators of the institute meet with international top athletes every morning on the way to work.

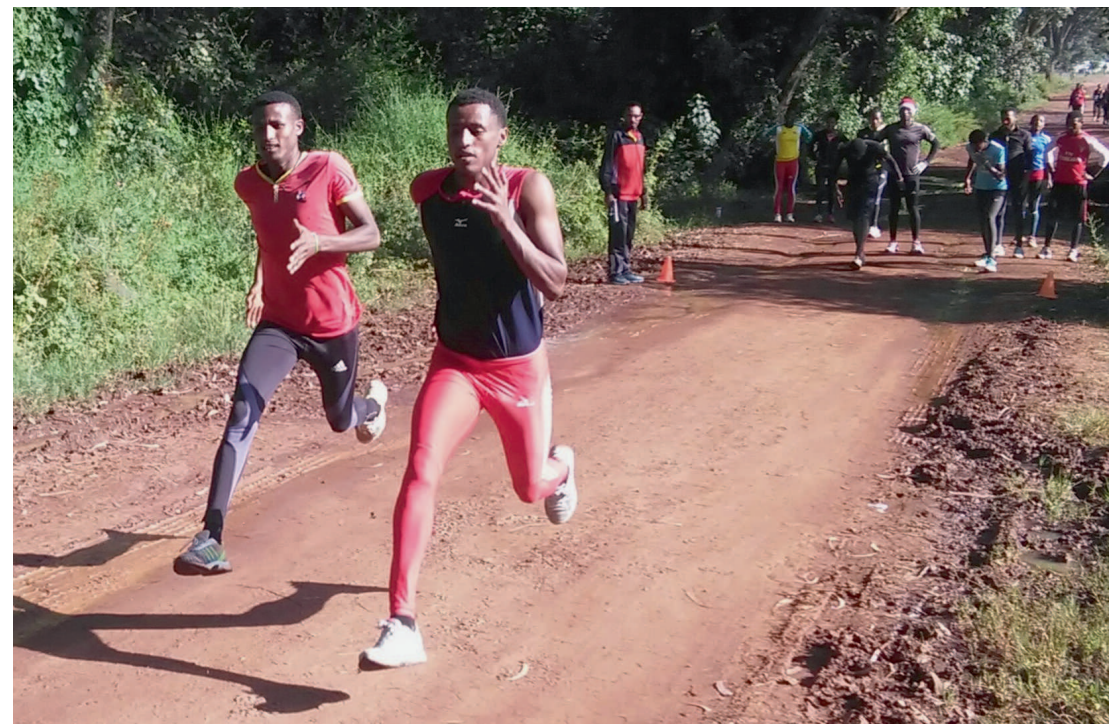

Professional marathon training in simple conditions: not all training exercises can be done at the new Athletics Training Center 


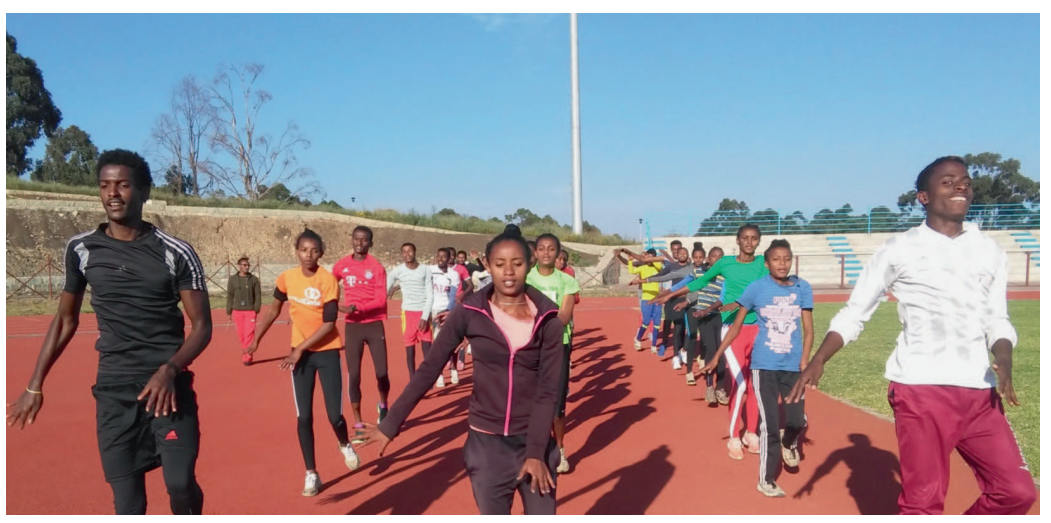

Group training sessions

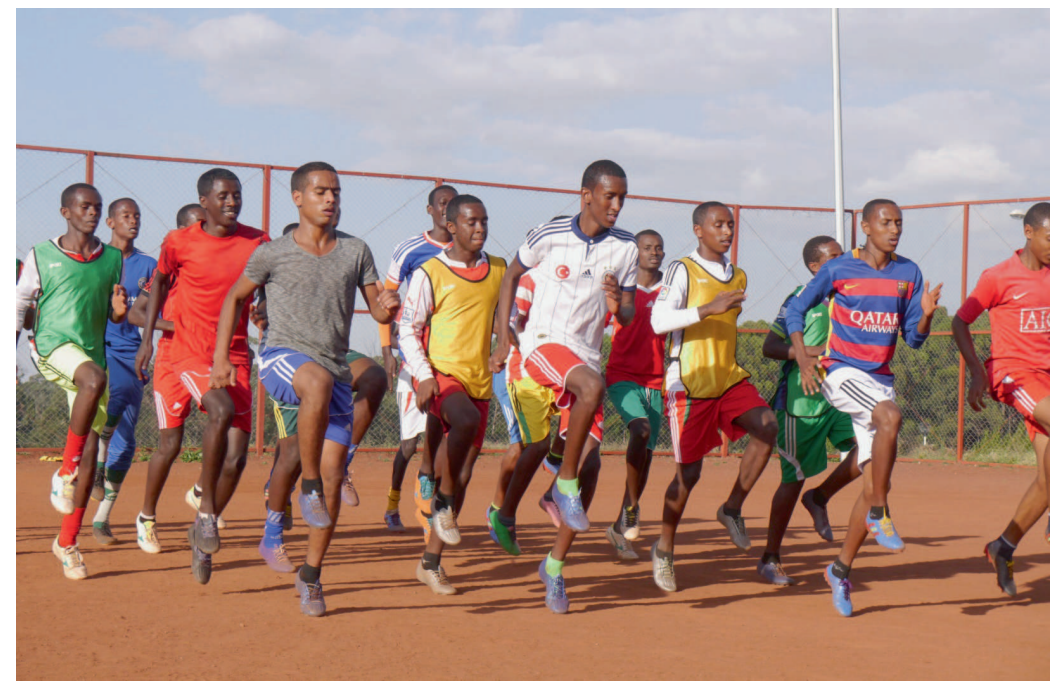

Young runners from Arsi 